University of Wollongong

Research Online

Faculty of Engineering - Papers (Archive)

Faculty of Engineering and Information

Sciences

$1-1-2011$

\title{
Roadside rest area wastewater treatment system: Performance evaluation and improvement
}

\author{
Adam Kiss \\ University of Wollongong \\ Faisal I. Hai \\ University of Wollongong, faisal@uow.edu.au \\ Long Nghiem \\ University of Wollongong, longn@uow.edu.au
}

Follow this and additional works at: https://ro.uow.edu.au/engpapers

Part of the Engineering Commons

https://ro.uow.edu.au/engpapers/2700

\section{Recommended Citation}

Kiss, Adam; Hai, Faisal I.; and Nghiem, Long: Roadside rest area wastewater treatment system:

Performance evaluation and improvement 2011, 389-396.

https://ro.uow.edu.au/engpapers/2700

Research Online is the open access institutional repository for the University of Wollongong. For further information contact the UOW Library: research-pubs@uow.edu.au 


\title{
Roadside rest area wastewater treatment system: performance evaluation and improvement
}

\author{
Adam Kiss, Faisal I. Hai*, Long D. Nghiem \\ School of Civil, Mining and Environmental Engineering, University of Wollongong, \\ Wollongong, NSW 2522, Australia \\ *Corresponding author: Email: faisal@uow.edu.au, Ph +61-2-4221-3054
}

\begin{abstract}
The performance of a decentralised sewage treatment plant located at a rest area servicing a major freeway was investigated. Long term monitoring and rigorous analyses undertaken in this study revealed several unique and challenging issues associated with such scarcely studied systems. Data collected over a six month period showed that the raw wastewater strength was well above typical household wastewater characteristics, with the average $\mathrm{BOD}_{5}$, COD, TOC, TN and TP values of 880, 4900, 350, 238 and $8 \mathrm{mg} / \mathrm{L}$, respectively. The system performance was considerably lower than that expected of a typical wastewater treatment unit. Several shortcomings in design (e.g., inefficient aeration device and return activated sludge system) and inconsistencies in maintenance practice were identified and some remedial measures were proposed and tested. Of particular interest were the increase of the dissolved oxygen (DO) concentration (from 0.5 to $4 \mathrm{mg} / \mathrm{L}$ ) and the simultaneous significant improvement of COD and TOC removals in the aerobic reactor in response to the redesigning of the aeration system. The removal of nitrogen, however, remained quite low as expected.
\end{abstract}

Keywords: Decentralised treatment plant, dissolved oxygen, mixed liquor suspended solids, roadside rest area, wastewater.

\section{Introduction}

The centralised wastewater treatment technology is well established with almost 100 years of history of development [1]. On-site systems, however, have traditionally been miniatures of larger scale systems rather than involving the application of scientific basis for the development of small scale technologies [2, 3]. They are becoming more important, particularly in areas not serviced by a centralised wastewater collection and treatment system [4]. On-site treatment systems are an attractive solution for rural areas where larger facilities are not feasible [5]. These systems can generally be installed at a quarter the price of centralised systems. On-site wastewater treatment systems are particularly relevant to Australia with its large road network and significant distances between urban areas. In 2004, Australia was serviced by up to one million on-site wastewater systems. This represented approximately 18-20\% of the Australian population, which relied on decentralised forms of treatment [6, 7].

Depending on the target effluent quality different technologies may be adopted for on-site wastewater treatment. Among them, the aerated wastewater treatment system (AWTS) has been one of the most widely used technologies. This technology was introduced in Australia in 1982 [8]; however it was not until 1985 that the AWTS received approval by the New South Wales (NSW) Department of Health [9]. While conceptually the AWTS should provide far improved performance over septic tanks, the reported performance data surprisingly shows 
somewhat different picture. A major disadvantage of the system is that the technology does not appear well understood and has led to a high failure rate. The AWTS has many components including several tanks, pumps, blowers, disinfection and irrigation systems and need to be monitored closely. In Australia the complete failure rate of AWTS has been as high as 40\% , while the instances of failure on at least one of the listed performance criteria has been counted up to $80-90 \%[10,11]$.

Roadside rest area comprises only a very small fraction of the worldwide onsite treatment systems. A report by Conn et al., [12] in 2006 found that service station on-site systems comprised of only $0.054 \%$ of the 500 million on-site systems worldwide. Hence, these systems are even more scarcely studied for monitoring or improvement purpose. In fact, our intensive literature review has indicated that studies on monitoring of the performance of decentralised sewage treatment systems for rest areas are virtually non-existent. However, the importance of monitoring such installations cannot be overlooked. Although the number of road side treatment systems is small, in most cases, the capacity of each system is significantly larger than the on-site wastewater treatment system used by a single household. Road side rest areas are located at remote sites and the treatment plant effluent is often disposed in the vicinity [13]. In absence of periodic monitoring, failure of sewage treatment plants at such locations means that any environmental pollution may remain unnoticed for long period. Therefore, in order to ensure the hygiene of the rest area users and avoid the burden on the pristine environment the roadside rest area sewage treatment plants need to be well designed and maintained.

To date onsite AWTS systems used in Australia have generally failed to meet the standard treatment performance. The situation may be even more severe for roadside service area systems which receive even less maintenance and monitoring efforts. In most cases the criteria for decentralised domestic treatment systems are adopted for designing the service area systems [12]. Rest area treatment facilities designed based on assumptions derived from decentralised domestic treatment systems may not be robust enough to withstand typical frequent peak loadings. There is also a risk that due to lack of monitoring any error in design will not be detected and rectified. In addition, the typical absence of trained personnel for the maintenance of such plants implies over-dependence on the plant maintenance recommendations pre-set by the packaged plant suppliers which may often be in contrary to the actual plant performance.

Given the above-mentioned backdrop of the dearth of studies on the performance of roadside rest area sewage treatment facilities, this paper reveals several unique and challenging issues associated with such installations. A holistic approach comprising of rigorous performance monitoring, problem identification and efficiency improvement is presented here.

\section{Materials and methods}

\subsection{Location and description of the treatment facility}

An on-site sewage treatment facility located at a rest area servicing a major freeway in Australia was selected for this case study. The rest area was completed in 2004 and consisted of a four toilet flushing system, an AWTS, a treated effluent storage dam and an effluent irrigation area. The rest area had a capacity to accommodate 15 trucks, buses or caravans and 30 cars at any given time.

Kiss, A., Hai, F. I. Nghiem, L. D. (2011). Roadside rest area wastewater treatment system: Performance evaluation and improvement. Desalination and Water Treatment, 32 389-396. 
The AWTS was a commercial packaged plant. A schematic layout of the AWTS is shown in Figure 1. Further detailed description of different components, wherever required, has been provided in the results and discussion section to avoid repetition.

\subsection{Sampling and analyses}

Grab samples were taken from each step of the treatment process. Depending on the parameter being measured samples were either collected in one litre Nalgene FEP bottles or $600 \mathrm{~mL}$ borosilicate glass containers. During sampling the container was placed vertically on a sample holder attached at the end of a fixed-length stick which allowed a representative sample from each tank to be collected. All analysis was conducted in accordance to the Standard Methods for Water and Wastewater examination [14]. The NSW Department of Health recommends a minimum of 3 sample periods to determine the operating efficiency of an on-site wastewater treatment facility. Based on this recommendation, a sampling plan of four days spanning over 6 weeks in August to September, 2008 was developed. Following the initial monitoring period, sampling was continued in a frequency of once a week for over six months to continuously assess the performance of the reactor in response to the modifications made.

\section{Results and discussion}

\subsection{Assessing existing wastewater loading and plant performance}

\subsubsection{Wastewater loading}

It was retrieved from discussion with the supervisor of the rest area that the package plant was initially designed around a maximum hydraulic loading of $3000 \mathrm{~L}$ per day and a wastewater loading similar to usual decentralised domestic treatment systems. There is no specific data, however, regarding the design wastewater strength. Actual check of the effluent flow and strength revealed the mismatch between the design data and the actual loading. An average daily flow of $3600 \mathrm{~L}$ was estimated during the monitoring period. It was further noted that the rest area treatment unit received a wastewater much stronger than what is usually considered as "high strength" (Table 1). This highlights the need for rest areas to be designed much more conservatively compared with domestic systems. They need to be robust enough to handle this high strength wastewater. Mismatch of design and actual loading may prove even more fatal if there are flaws in the process units design. As discussed in the subsequent sections, this was exactly the case in this study.

\subsubsection{Performance of the AWTS}

In simple visual inspection the balance tank, aerobic reactor, and pump out tank appeared to have very similar characteristics, indicating limited removal in the aerobic tank. This was later confirmed in thorough testing of the samples. It was also noted that the effluent lagoon was of a dark green colour which indicated a high level of algal growth. This high level of algae showed that the AWTS was failing to remove nutrients from the effluent prior to discharge.

The test results for wide varieties of monitored parameters are shown in Table 2. The removal efficiency has been compared with the NSW Department of Health performance criterion. The

Kiss, A., Hai, F. I. Nghiem, L. D. (2011). Roadside rest area wastewater treatment system: Performance evaluation and improvement. Desalination and Water Treatment, 32 389-396. 
effluent failed to comply with the regulated criteria with respect to all the parameters except TP. It should be noted, however, that instead of discharging directly to the environment the facility discharged the effluent via an irrigation plot as per a license issued by the environmental protection agency. Issues with excessive TSS and organic matter loading on soil include the physical clogging of soil pores which will favour anaerobic soil microbes and can lead to slimy bacterial scum coating the soil, blocking pores and closing up cracks [15]. No such issues were identified with the studied irrigation plot during the monitoring period. However, as the final effluent from the plant was above the recommended guidelines, continual overloading of the site can lead to a reduction in the effective life of an irrigation plot.

The following paragraphs will look more closely at the removal rates of the major parameters at the site.

The only significant reduction (78\%) in $\mathrm{BOD}_{5}$ was achieved in the anaerobic tank. This is quite acceptable and above the benchmark of $60 \%$ reduction of $\mathrm{BOD}_{5}$ in a septic tank [16]. The removal rate in the aerobic tank can be calculated based on the concentration in the balance tank (following the anaerobic tank) and the pump out tank (following the aerobic tank). The removal of $\mathrm{BOD}_{5}$ in the aerobic reactors (40\%) was well below other AWTS which have reported removals in excess of $80 \%$ with some manufacturers claiming to reduce $\mathrm{BOD}_{5}$ by up to $98 \%$ [9, 17]. The effluent COD and TOC values further highlighted the poor performance of the aerobic reactor. The reactor achieved only $24 \%$ and $4 \%$ reduction in TOC and COD, respectively. A further reduction of $60 \%$ of $\mathrm{BOD}_{5}$ occurred in the effluent lagoon, probably because it acts as a low mass biological reactor[1]. However, the final concentration exceeded the $30 \mathrm{mg} / \mathrm{L}$ guideline set by the NSW Department of Health.

The TSS in a similar fashion to $\mathrm{BOD}_{5}$ was also only significantly reduced in the anaerobic tank. A reduction of $98 \%$ in TSS from the septic tank was observed. This reduction is typical with TSS removal from septic tanks [16]. The removal through the aerobic reactor was $47 \%$. This is well below what one would expect from a properly functioning AWTS. Typical removal rates should be in excess of $90 \%$ with some manufacturers claiming up to $98 \%$ removal of TSS [9, 17]. It should also be noted that the TSS concentration actually increased by $120 \mathrm{mg} / \mathrm{L}$ after being discharged into the effluent lagoon, with the final concentration at $159 \mathrm{mg} / \mathrm{L}$. There was a large amount of algal growth in the lagoon, due to the limited nutrient removal as discussed below.

In traditional treatment plants phosphorus is usually removed via chemical precipitation with the aid of iron and aluminium. On the other hand nitrogen removal can be improved through modification of the treatment process to provide an anaerobic/anoxic step or by adding further treatment processes [18]. Therefore, in absence of such additional measures, in a standard packaged AWTS the removal of phosphorus can only be expected to be in the range of 10-20\% whereas nitrogen removal is in the range of 15-25 \% [19]. However, the nutrient removal in the studied plant was virtually non-existent. This result is not entirely unexpected considering the removal rates of $\mathrm{BOD}_{5}$ and TSS. It can be added that $\mathrm{TN}$ concentration was reduced by a further $43 \%$ in the effluent lagoon. This would be attributed to a minor amount of nitrification/denitrification and mostly due to the algal uptake in the lagoon [1].

\subsection{Identification of probable reasons for underperformance}

Kiss, A., Hai, F. I. Nghiem, L. D. (2011). Roadside rest area wastewater treatment system: Performance evaluation and improvement. Desalination and Water Treatment, 32 389-396. 
In order to ensure safe disposal of wastewater it was required to pinpoint the reasons for inefficiency of the treatment plant. Detailed analyses of the measured parameters as listed in Table 2 enabled pointing out the probable reasons for the inefficient removal performance. The important issues are discussed below.

\subsubsection{Aerobic Mixing and Dissolved Oxygen Concentrations}

It was noticed that the dissolved oxygen (DO) throughout the major portion of the aerobic reactor was below $1 \mathrm{mg} / \mathrm{L}$. Testing confirmed that the aerator could provide up to $5 \mathrm{mg} / \mathrm{L}$ of DO; however this level was very localised (directly below aerator) and not uniform throughout the reactor. In the bottom of the tank and in the adjacent manhole the DO was $<0.5 \mathrm{mg} / \mathrm{L}$. The DO concentration in the aerobic reactor is critical to the performance of the unit. The amount of oxygen required for activated sludge plants varies depending on the configuration, amount of carbonaceous oxidation and level of nitrification and de-nitrification required [1]. For a small scale AWTS the recommended minimum DO value is $2.0 \mathrm{mg} / \mathrm{L}[13,19]$, while other studies have suggested values of up to $5.0 \mathrm{mg} / \mathrm{L}$ [17].

In order to find out the reason of inefficient DO distribution, a closer inspection of the aerator was required (Figure 2). The manufacturer used a rotating aeration device which supplied air from atmosphere through the vent and injected it into the tank while circulating the entire contents. It was instantly conceivable that as the tank is baffled (Figure 2a), the mixing in one section would not translate to effective aeration in the adjacent section. There were also some concerns with the location of the aerator. The aerator was positioned at the top of the tank and injected air into the upper $0.15 \mathrm{~m}$ surface above the biomass panels. Ideally the air would need to be diffused below these panels.

\subsubsection{MLSS concentration}

The MLSS is an indicator on the amount of activated sludge in the chamber. Depending on the configuration i.e. suspended growth or hybrid system, the MLSS in AWTS should be in the range 2000-6000 mg/L [19]. Maintaining the correct MLSS ensures that the food to micro-organism (F/M) ratio is in the right balance [1]. Table 2 shows that the MLSS in the aerobic reactor was very low. Accordingly it created a high $\mathrm{F} / \mathrm{M}$ ratio and effectively reduced the $\mathrm{BOD}_{5}$ and nutrient removal efficiencies. In a combined suspended and attached growth reactor the biomass attached on the support too needs to be taken into account. The aerobic reactor in this study housed $177 \mathrm{~m}^{2}$ of biomass panels (Figure 2 c,d). During a planned servicing of the aerobic reactor the biomass panels appeared heavily clogged (Figure 2 c). Apparently insufficient mixing led to the accumulation of anaerobic bacteria on the panels, and accordingly removal performance was poor. In addition to the insufficient DO, two other design issues were pointed out as causing low MLSS in the aerobic tank. It was noted that the return activated sludge (RAS) pump was diverting the RAS back into the anaerobic tank. The primary purpose of a RAS pump is to maintain a sufficient concentration of activated sludge in the aeration tank, so the desired level of treatment can be achieved in the optimum time frame [1]. As gathered from discussion with the supervisor of the rest area, the RAS pump was installed as a means of reducing sludge in the final clarifier, not for maintaining the appropriate MLSS in the aerobic tank. Apparently digestion of excess sludge in the anaerobic tank was the initial aim. However, such a practice was in contradiction to 
the very low MLSS concentration in the aerobic tank. This was exacerbated by the fact that instead of taking into consideration the actual MLSS concentration, the sludge from the aerobic tank was pumped out every 6 months following the manufacturer's preset recommendations.

\subsubsection{Hydraulic Retention Time (HRT)}

There are three sections of the studied treatment facility in which HRT needs to be incorporated into the design, the septic tank, aerobic reactor and the secondary clarifier. A reduced HRT has an effect on some or all of these stages. For instance, a poorly functioning septic tank will affect the loading in the aerobic reactor. The required HRTs for different tanks vary widely throughout the literature; however, values somewhere in the range of 1-5 days [16], 1-5 days [9, 17] and 0.251 day [9, 17] for septic tank, aerobic tank and secondary clarifier, respectively, are generally accepted. It should be noted that in all the instances the applied HRT in this study was operating at the bottom end of the recommended limits (Figure 1). The bottom end of these limits assumes that the entire treatment plant is operating efficiently, which was not the case. The analysis of the HRT failed to highlight any glaring issues with the applied HRTs. The poor performance was more related to a poorly functioning aerobic tank rather than the HRT.

\subsection{Attempts to improve performance}

In order to confirm that the DO and MLSS problems were interrelated, the improvements were made step by step as illustrated in section 3.3.1 and 3.3.2.

\subsubsection{Seeding to kick-start the aerobic system}

The initial results clearly showed that the only tank showing any signs of removal efficiency was the anaerobic tank (Table 2). To try and kick start the system, activated sludge (MLSS 2000 $\mathrm{mg} / \mathrm{L}$ ) was collected from the Wollongong sewage treatment plant and seeded into the aerobic reactor. Figure 3a shows the COD removal efficiency and MLSS concentration in the aerobic tank before and different intervals after seeding. A temporary marginal improvement in removal performance was observed after the seeding. This indicated the importance of maintaining adequate level of MLSS concentration in the reactor. However, the plummeting removal rate and MLSS concentration over time underscored that without improving the DO level, accumulation of aerobic bacteria on the biomass panels would not be possible, and washout of suspended sludge would be inevitable. This confirmed that the DO and MLSS problems were interrelated.

\subsubsection{DO improvement}

Martin [20] previously reported improved removal performance in a package aerobic treatment system by installing a blower which can supply 100L/min of air. Accordingly a diffuser was installed at the bottom of the aerobic tank and was connected to a blower (6/24 min on/off, $100 \mathrm{~L} / \mathrm{min}$ ). Figure $3 \mathrm{~b}$ shows the DO profile over the rector depth before and after the installation. A homogenous and markedly improved DO concentration could be sustained due to the change of the aeration system. It is worth noting that the DO level did not drop below $2 \mathrm{mg} / \mathrm{L}$ level even during the off period of the blower. Figure 3c shows the stable improvement in COD, TOC and TN removal in the aerobic tank due to the improvement of the DO level. The removal efficiency of COD, TOC and TN improved from $4 \%, 24 \%$ and negligible level to $44 \%, 61 \%$ and $19 \%$, 
respectively. It should be noted that despite the improved performance, the MLSS in the reactor did not improve significantly. However, visual observation confirmed that a steady level of biomass was attached onto the panels. With $177 \mathrm{~m}^{2}$ of biomass media and an assumed average biomass density of $100 \mathrm{~g} / \mathrm{m}^{2}$ in line with the literature reports [21], the total amount of attached biomass can be estimated as $17700 \mathrm{~g}$, which, if considered distributed over the whole volume of the reactor $(6500 \mathrm{~L})$, is equivalent to an MLSS of $2700 \mathrm{mg} / \mathrm{L}$. This is a reasonable concentration in line with the observed removal performance. Apparently due to the efficient aeration the panels maintained an active mass of aerobic bacteria which gave rise to the observed improved removal performance.

In order to ensure that final effluent complies with the NSW Department of Health Guidelines, study is underway to assess whether directing the RAS back to the aerobic tank would result into increase in MLSS concentration and further improvement of the removal performance.

\section{Conclusions}

Not one system can be pigeon holed into being the only solution for on-site wastewater treatment at rest areas. Through a case study this paper reveals several unique and challenging issues associated with roadside rest area wastewater treatment systems. This research pointed out the common flaws in design considerations of decentralised sewage treatment plants (especially those located in the roadside rest areas) and also raised concerns about the issues including insufficient monitoring and over-dependence on manufacturer's instructions rather than application of judgment. The results from our study highlight that on-site systems need to be designed for specific sites based on realistic loading criteria. Systems should be in place to allow easy upgrade in plant settings based on the real performance after commissioning of the plant. By their very nature, rest areas are located at remote sites. As such it may not be feasible to arrange for regular maintenance visits and will also need to be robust enough to handle the sudden shocks of peak periods. A prudent monitoring system encompassing assessment of the key parameters needs to be in place. This would ensure proper functioning of the plant even with the intermittent mode of monitoring. This study systematically analysed the shortcomings of the plant design, identified the underlying reasons for underperformance and proposed and tested simple but sustainable solutions. Information revealed through this study is of paramount importance for future roadside rest area installations.

\section{REFERENCES}

1. Tchobanoglous, G.; Burton, F. L.; Stensel, H. D., Wastewater engineering: treatment and reuse. 4th ed.; McGraw-Hill: Boston, 2003; p xxviii, 1819 p.

2. Ho, G., Localized treatment and reuse of wastewater: Science, technology and management. Desalination 1996, 106, (1-3), 291-294.

3. Tadkaew, N., Sivakumar, M., Nghiem, L.D. , Membrane bioreactor technology for decentralised wastewater treatment and reuse. International Journal of Water 2007, 3, (4), 368-380.

4. $\quad$ Carroll, S.; Goonetilleke, A.; Thomas, E.; Hargreaves, M.; Frost, R.; Dawes, L., Integrated risk framework for onsite wastewater treatment systems. Environmental Management 2006, 38, (2), 286-303. 5. McCray, J. E.; Christopherson, S. H., On-site wastewater systems and interactions with the environment. Journal of Hydrologic Engineering 2008, 13, (8), 653-654.

Kiss, A., Hai, F. I. Nghiem, L. D. (2011). Roadside rest area wastewater treatment system: Performance evaluation and improvement. Desalination and Water Treatment, 32 389-396. 
6. Diaper, C. Innovation in on-site domestic water management systems in Australia: A review of rainwater, greywater, stormwater and wastewater utilisation techniques; 2004-073; CSIRO Urban Water: Canberra, April 2004, 2004.

7. O'Keefe, N., Towards National Consistency for Accreditation of On-site Installation and Service Personnel. In Proceedings of On-site of On-site '01, Patterson, R., Ed. Lanfax Laboratories: Armidale, 2001; pp 279-285.

8. Martin, R., Measuring Compliance Against the NSW Government's AWTS Guideline. In Proceedings of On-site of On-site '03, Patterson, R., Ed. Lanfax Laboratories: Armidale, 2003; pp 249-256. 9. Ivery, G., Aerobic treatment units (ATUs): appropriate technology for on-site wastewater treatment and re-use. Desalination 1996, 106, (1-3), 295-303.

10. Gunn, I., Field Performance Monitoring - On-site Domestic Wastewater Treatment Plants. In Proceedings of On-site of On-site '05, Patterson, R., Ed. Lanfax Laboratories: Armidale, 2005; pp 225-232. 11. Hodges, N., Maintenence and Approval of On-site sewage Treatment Systems. In Proceedings of On-site of On-site '01, Patterson, R., Ed. Lanfax Laboratories: Armidale, 2001; pp 185-192.

12. Conn, K. E.; Barber, L. B.; Brown, G. K.; Siegrist, R. L., Occurrence and fate of organic contaminants during onsite wastewater treatment. Environmental Science and Technology 2006, 40, (23), 7358-7366.

13. NSWHealth Sewage Management Facility - Sewage Treatment Accreditation Guideline; Part 4, Clause 41(1); NSW Department of Health: 2005.

14. American Public Health Association.; American Water Works Association.; Water Pollution Control Federation., Standard methods for the examination of water and wastewater. In American Public Health Association.: New York,, 2007; Vol. 21st edition.

15. New South Wales. Dept. of Environment and Conservation., Environmental guidelines : use of effluent by irrigation. Dept. of Environment and Conservation (NSW): Sydney, [ N.S.W.], 2004; p xi, 121 p.

16. Al-Jamal, W.; Mahmoud, N., Community onsite treatment of cold strong sewage in a UASB-septic tank. Bioresource Technology 2009, 100, (3), 1061-1068.

17. Michael Hanna, K.; Lee Kellam, J.; Boardman, G. D., Onsite aerobic package treatment systems. Water Research 1995, 29, (11), 2530-2540.

18. Ra, C. S.; Lo, K. V.; Shin, J. S.; Oh, J. S.; Hong, B. J., Biological nutrient removal with an internal organic carbon source in piggery wastewater treatment. Water Research 2000, 34, (3), 965-973. 19. USEPA, USEPA Onsite Wastewater Treatment Systems Manual. In USEPA, Ed. USEPA: Washington, 2002.

20. Martin, R., Performance and Testing of Aerated Wastewater Treatment Systems. In Proceedings of On-site of On-site '01, Patterson, R., Ed. Lanfax Laboratories: Armidale, 2001; pp 279-285.

21. Comett, I.; Gonzalez-Martinez, S.; Wilderer, P., Treatment of leachate from the anaerobic fermentation of solid wastes using two biofilm support media. Water Science and Technology 2004, 49, (11-12), 287-294.

Kiss, A., Hai, F. I. Nghiem, L. D. (2011). Roadside rest area wastewater treatment system: Performance evaluation and improvement. Desalination and Water Treatment, 32 389-396. 
LIST OF TABLES

320 Table 1: Design vs actual wastewater loading

\begin{tabular}{|l|c|c|cr|}
\hline \multicolumn{1}{|c|}{ Parameter } & Unit & Actual & \multicolumn{2}{c|}{ Typical high strength $^{\mathbf{a}}$} \\
\hline COD & $\mathrm{mg} / \mathrm{L}$ & 4900 & 800 & 322 \\
\hline BOD $_{5}$ & $\mathrm{mg} / \mathrm{L}$ & 880 & 350 & 323 \\
\hline TS & $\mathrm{mg} / \mathrm{L}$ & 5800 & 1230 & 324 \\
\hline TSS & $\mathrm{mg} / \mathrm{L}$ & 3400 & 400 & 325 \\
\hline TOC & $\mathrm{mg} / \mathrm{L}$ & 350 & 260 & 326 \\
\hline TN & $\mathrm{mg} / \mathrm{L}$ & 238 & 70 & 327 \\
\hline TP & $\mathrm{mg} / \mathrm{L}$ & 8 & \multicolumn{3}{c|}{12} & $10^{5}-10^{8}$ & 328 \\
\hline Faecal coliform & cfu/100mL & $10^{7}-10^{8}$ & \multicolumn{3}{|c|}{328} \\
\hline
\end{tabular}

${ }^{\mathrm{a}}$ From [1]. 
Table 2: Summary of results obtained from initial testing

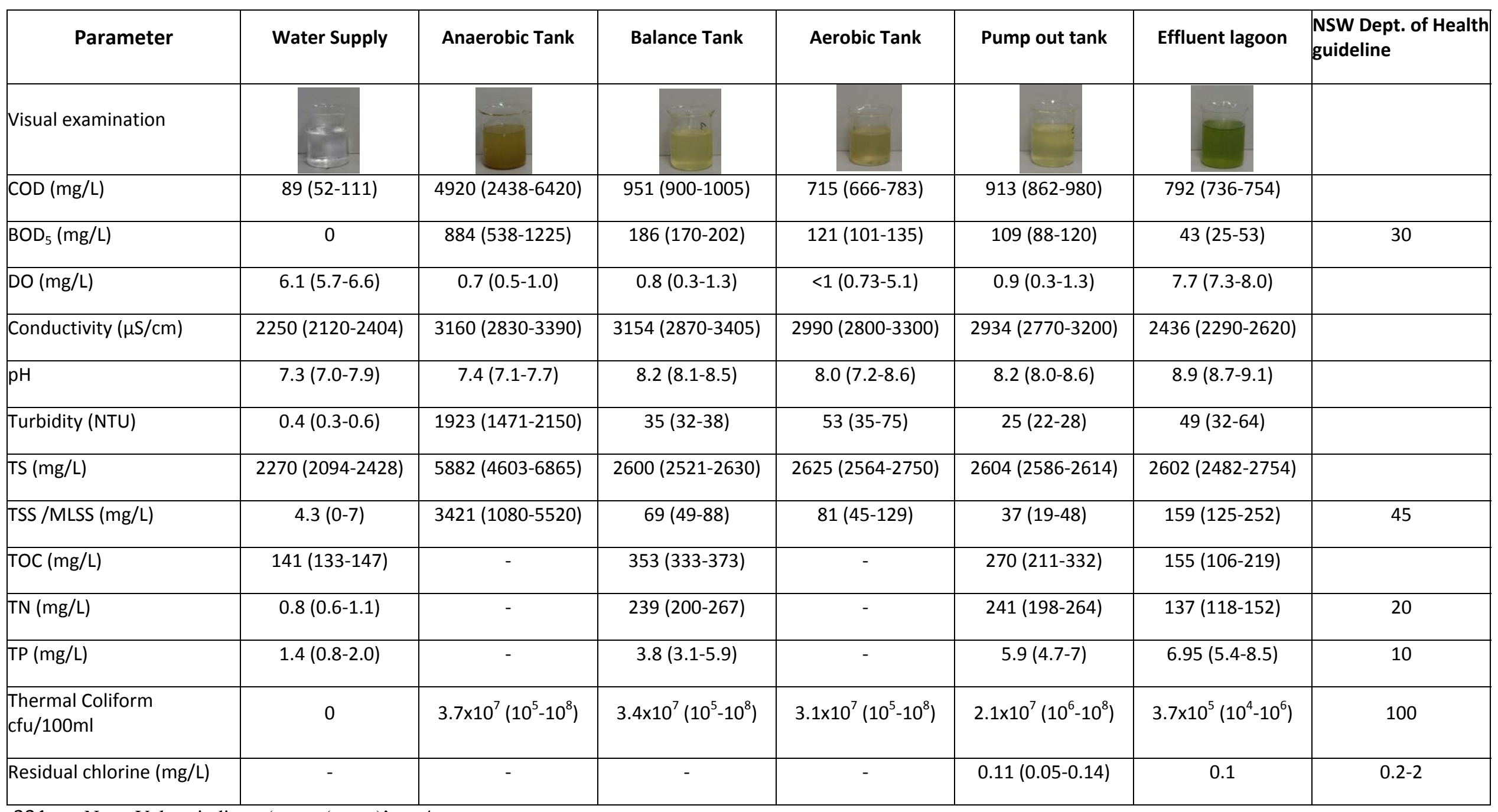

331 Note: Values indicate 'mean (range)'; $n=4$

Kiss, A., Hai, F. I. Nghiem, L. D. (2011). Roadside rest area wastewater treatment system: Performance evaluation and improvement. Desalination and Water Treatment, 32 389- 


\section{LIST OF FIGURES}

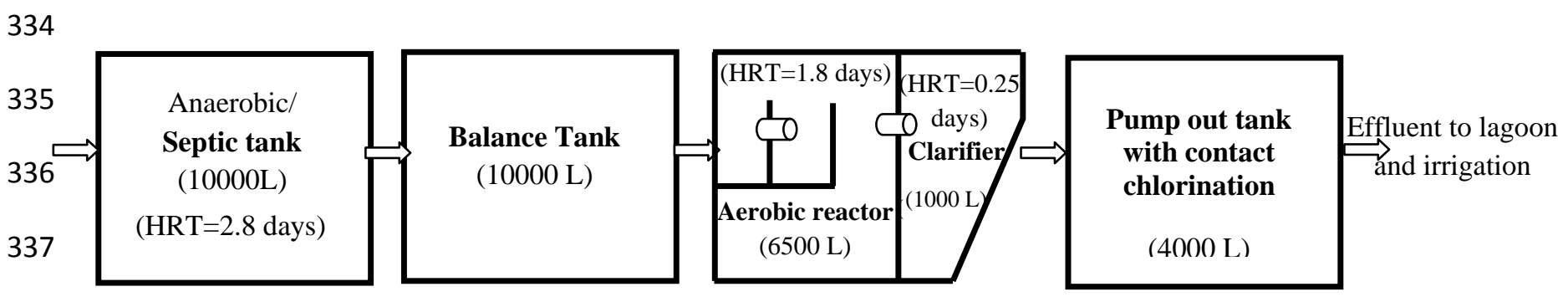

338

339 Figure 1: Layout of the AWTS (not to scale)

340

341

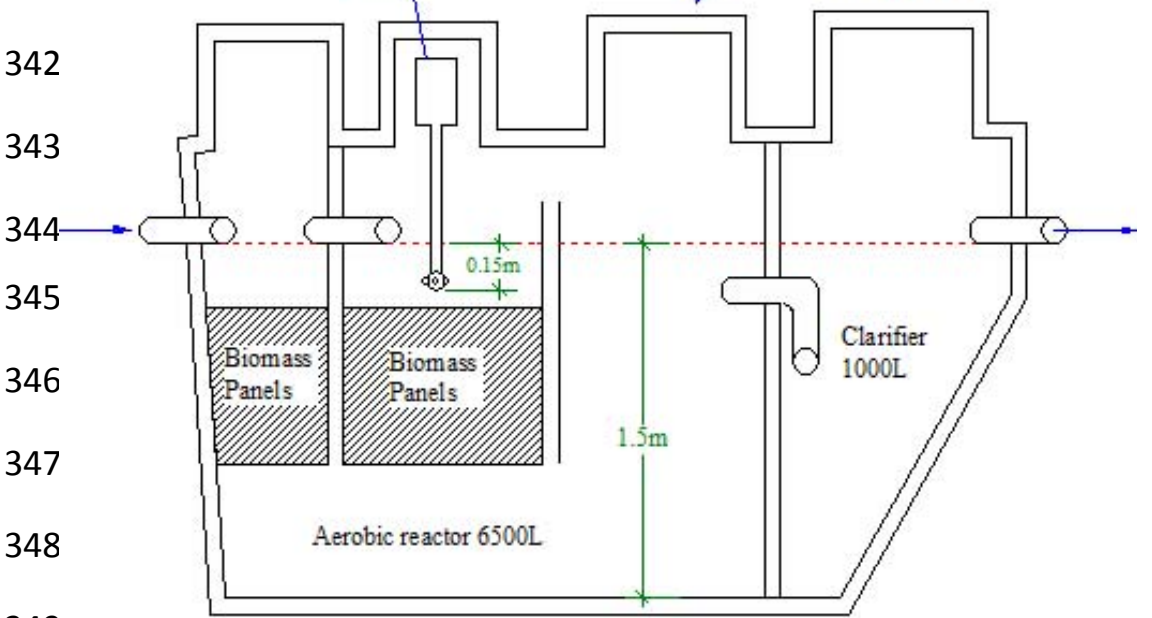

349

(a)

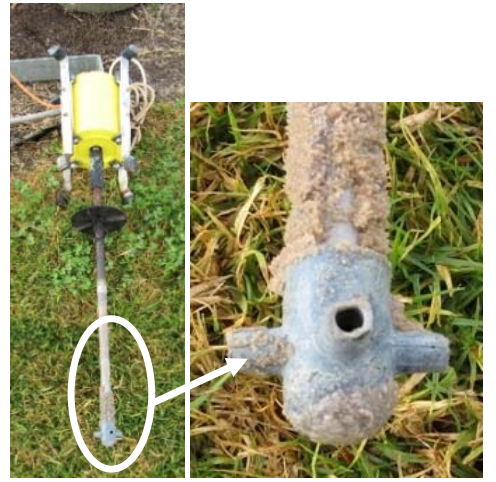

(b)

350

351

352

353

354

355

356

(c)

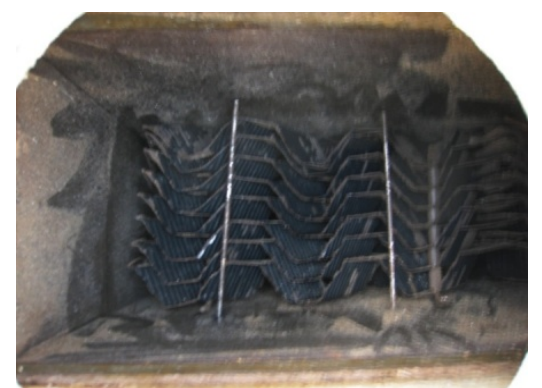

(d)

357 Figure 2: Identification of reasons for plant underperformance

358 (a) Configuration of the aerator in the aerobic tank, (b) Closer look at the aerator, (c) Biomass 359 panels heavily clogged with anaerobic biomass, (d) Biomass panel after servicing.

Kiss, A., Hai, F. I. Nghiem, L. D. (2011). Roadside rest area wastewater treatment system: Performance evaluation and improvement.

Desalination

and

Water

Treatment,

32

389-396. 


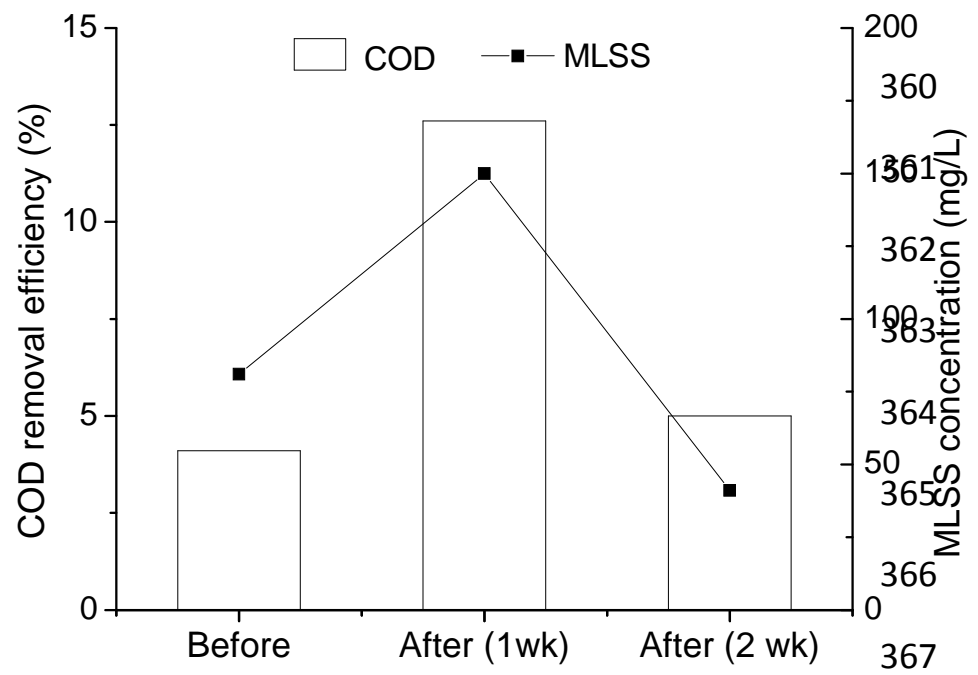

(a)

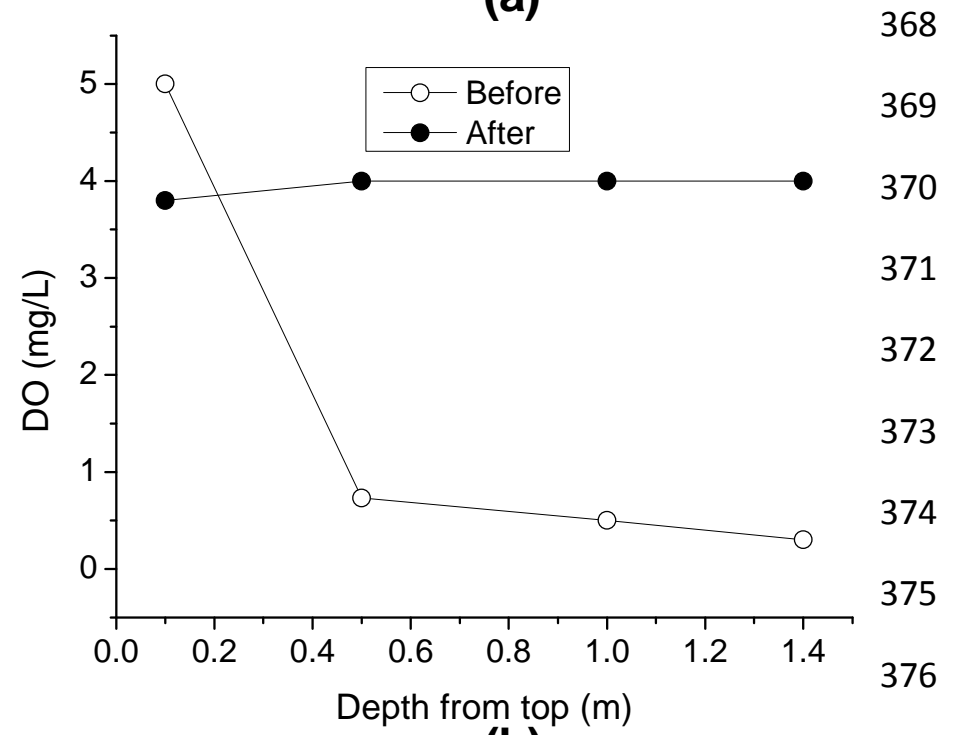

(b)

377

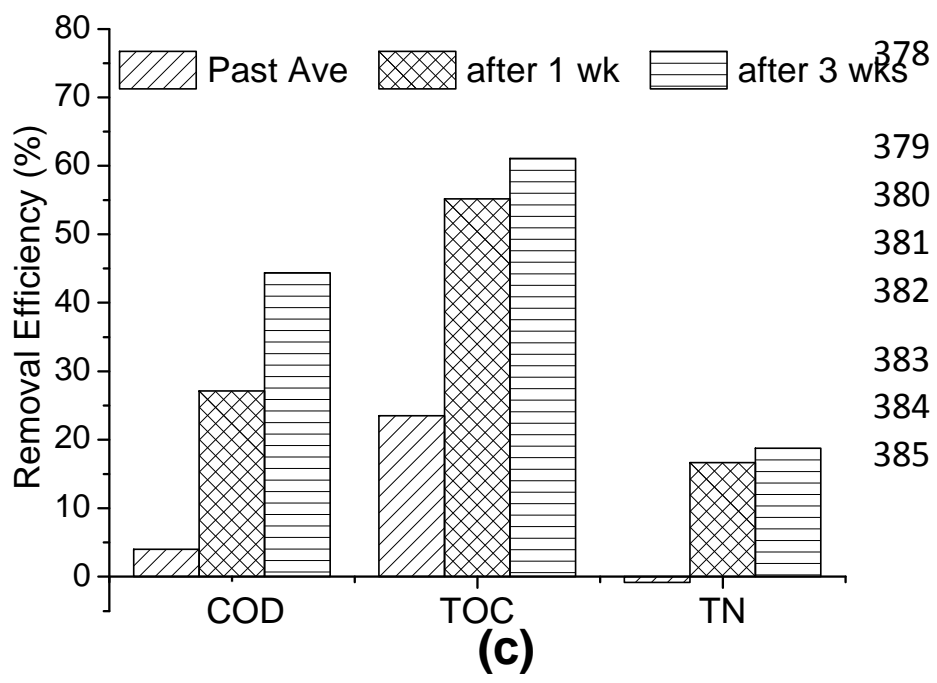

Figure 3: Implications of different attempts to improve performance

(a) Effect of seeding of aerobic reactor without improving DO level (b) Homogenous DO level maintained after installation of the air blower.

(c) Performance of the aerobic reactor before and after the installation of the blower.

Kiss, A., Hai, F. I. Nghiem, L. D. (2011). Roadside rest area wastewater treatment system: Performance evaluation and improvement. Desalination and Water Treatment, 